\title{
Women in mediation and conflict resolutions: Lessons, challenges, and prospects for Africa.
}

\author{
Elizabeth Terngu Sugh *, Agnes Ikwuba** \\ Department of Sociology, Benue State University, Makurdi, Nigeria.*
}

\begin{abstract}
Over the past decades, women have been involved in mediation and conflict resolution processes. However, their roles remain largely undervalued and unrecognized in this processes. In spite of this, women devise all manner of strategies within their reach to resolve conflicts and bring about peaceful co-existence. This paper uses Somalia and Kenya women's case studies to expose various strategies used by women in mediation and conflict resolutions. The use of poetry and the 'spitting' initiatives were important strategies and processes used by these women to effectively mediate and return their disputant societies back to peace. The major gaps identified by their strategies were; the non-inclusion of women's needs in peace processes, and inadequate lobbying by women in the implementation of treaties that affects them. The paper recommends amongst others, aggressive sensitization of stakeholders at all levels to appreciate women's involvement in conflict resolution processes, increased training of women mediators and negotiators to help strengthen women's involvement at all levels of mediation and conflict resolution processes.
\end{abstract}

Keywords: Women, mediation, conflict resolution

\section{INTRODUCTION}

In every human interaction, there is bound to be conflict. Conflict is often fuelled by deeply engrained divisions over resources, power, mistrust, and exclusionary politics. To the functionalist school of thought, conflict is necessary for the effective survival of society. However, when conflict is persistent and unresolved, it becomes destructive to society and retards societal development. Conflicts such as those in most African countries including Somalia, Sierra- Leone, Liberia, Uganda, South Africa, Nigeria, and elsewhere are counterproductive; as they often lead to destruction of lives and properties, violates fundamental human rights especially those of women and damages relationships between the disputants. Even though women are rarely the initiators of conflicts, women and children often suffer the daunting and humiliating consequences of both armed and civil conflicts. Frechette (2001) corroborated this position when he stated that, women are strategically targeted as a way to humiliate the adversary and break the morale and resistance of whole societies. Rape, forced pregnancies, sexual slavery and assault are often used as deliberate instruments of warfare. Despite these effects of conflicts on women, many of them are still able to get involved in the processes of conflict resolution.

Although, conflict affects every member of the society in varying degrees, women are naturally more prone to negotiate for peace than men, and in achieving this, women devise all available strategies and resources within their reach to mediate and resolve conflicts for peace to reign. For instance, Gardners \& E-Bushra (2009) posited that, in order to achieve peace processes women go as far as holding prayer meetings, marches, night vigils, and in some cases as alluded in the Sudan case study, withhold sexual services from their partners or shamed authorities into negotiating by appearing naked in public demonstrations. The extent to which women devise both formal and informal initiatives to bring about peace shows that women are a formidable force to reckon with in mediation and conflict resolution and must be well integrated in these processes.

The importance of this integration can be succinctly explained from the functionalist perspective as postulated by Emile Durkheim (1917) that, society is a system of interlinked parts that, when in balance, operate smoothly to produce social solidarity. The functionalist perspective implies that, unless women are well incorporated in these processes and initiatives, there can be no sustainable conflict prevention, peace or solidarity in the society.

Another dimension of the problem is that common obstacles within the African continent such as deeply entrenched patriarchal values which perceives women as second class citizens and undervalues their roles, to a large extent, have limited women from adequately being recognized as central key players in these processes. An indication that, women's powerful potentials in bringing war torn societies back to peace are not fully utilized in mediation and conflict resolution within the continent. A lot of documented literature has already exposed the impact of exclusionary practices concerning women vis-a-vis conflict resolution. This 
paper therefore examines past processes and initiatives devised by women in mediation and dispute resolutions using the Somalia and Kenya experiences. It also exposes how such strategies can be further used to enhance women's integration in mediation and conflict resolutions. The paper concludes by exposing the common challenges, and the prospects for African women.

\section{CLARIFICATION OF CONCEPTS}

Some key concept employed in this study need clarifications. These include the following:

2.1 Mediation: Due to the inevitability of conflicts, in society, formal conflict resolution mediums like courts were developed and have been in use till date. However, due to increasing challenges of delay, high cost amongst others, society began to utilize alternative dispute resolutions methods outside of litigation. Mediation is one of the informal methods of conflict resolutions, used in conflict prevention, management, resolution and peace building. Lynch (2001); and Alexander, (2009) defines mediation as a facilitative form of conflict resolution, which focuses on the parties' commercial, financial, as well as social and personal interest, with the aim of reaching a mutually acceptable agreement while promoting the principles of confidentiality, autonomy, and informed consent in decision making. In mediation, there is a third party, a mediator, who facilitates the resolution process, and may even suggest a resolution, but does not impose a resolution on the parties. Conflict resolution is one major goal of all alternative dispute resolution processes. If a process leads to a resolution, it is a conflict resolution process. Thus, mediation is a conflict resolution process. In some countries, mediation is equated to alternative dispute resolution.

2.2 Conflict resolution: Conflict resolution is employed in this study to mean a process that resolves or ends conflicts. It can also be viewed as a non-violent process that manages conflict through compromise or through the assistance of a third party who either facilitates or imposes a settlement or resolution. Typically, non-adversarial practices such as mediation, negotiation, arbitration and conciliation are practices that have been associated with conflict resolution or alternative dispute resolution procedures (Boulder, 1996).

\section{IMPORTANCE OF MEDIATION IN CONFLICT RESOLUTION}

Alexandra (2009) posits that, the flexibility of the mediation process allows it to address different cultures, relationships and interest and puts it in a better position to design a process which is acceptable to all participants. Similarly, Goldberg et al (2007) stated that, due to the accommodation of cultural differences, mediation leads to greater satisfaction of parties with the process and the results, higher compliance of mediated agreement and the whole process is more likely to improve the relationship between the disputants than is adjudication. In the same vein, Colin (2007) reported that, mediation has led to the resolution of many intractable armed conflict in Africa in the past two decades as a result of negotiated settlements which were achieved through mediation. On the whole, mediation is a good tool for conflict resolution, and helps rebuild relationships that have been destroyed by conflicts, and since women have proven to be good mediators, it will benefit societal development, if women are more actively incorporated in conflict resolution process.

\section{STRATEGIES/INITIATIVES ADOPTED BY WOMEN IN MEDIATION AND CONFLICT RESOLUTION}

This section x-rays the background of conflicts in both Somalia and Kenya. It also highlights the strategies and initiatives used by women in both countries in mediation and conflict resolution processes.

\subsection{A case study of Somalia}

In 1991, an armed uprising that began in the northern parts of Somalia in the early 1980's engulfed the capital, Mogadishu, forcing out the military dictatorship of Siyad Barre. Once the regime fell, Somalia, imploded into civil war between clan- based military factions. Four months of fighting in 1991-1992 killed over 25,000 people. With the collapse of the state, the political vacuum that followed the collapse of the Barre regime was immediately filled by a violent power struggle between clan based factions over control of Mogadishu and Southern Somalia resources. A UN Peace Keeping Mission (UNOSOM) from 1992-1995 failed to end the the violence and restore a government (Jama, 2009; Anneltto, 2006). The early 2000's saw the creation of fledging Interim Federal administration, culminating in the establishment of the Transitional federal Government (TFG). In 2006, the TFG assisted by Ethiopian troops assumed control of most part of the nations Southern conflict zones from the newly formed Islamic Courts Union (ICU). The ICU subsequently splintered to more radical groups and the resulting violence was widespread and brutal. Representatives of the Somalia's federal government and the moderate Alliance for the Re-liberation of Somalia (ARS) groups of Islam rebel participated in peace talks in Djibouti in 2008, brokered by the special United nations special Envoy to Somalia. The conference ended with the signing of an agreement, calling for the cessation of armed confrontation. In 
2011, a coordinated military operation between the Somali military and multinational forces began which is believed to represent one of the final stages in the war's Islamist insurgency.

Somalia women during the civil war emerged as crucial mediators and peacemakers. For instance, When the war was at its peak, and fierce, warfare raged between rival clans in the 1990's, warlords failed to reach an agreement in twelve (12) reconciliatory meeting. During this period, Somali women were able to play the role of peace envoy and messengers. They employed a mediation strategy of using poetry as a method to promote peace and tranquility. They recited their 'buraambur' to humble the men and compelled them to accept the messages portrayed in the female poetry, they also recited poems with messages of 'male power grabbing and selfishness' which left many men in tears and afterwards, the elders agreed to allocate women 12percent seats in the administration (Jama 2009, Ingiri, 2012). Hitherto, Somali women's roles in helping to sustain dialogue in times of conflict were unrecognized and women were only allowed as observers at the formal conferences, and denied voting rights (Jama, 2009).

The above indicates that, the strategies adopted by Somali women through recitation of poems helped to make their roles in mediation and conflict resolution more visible and gave them opportunities to be involved in decision-making processes in the parliament. In addition, Somali women challenged civil society to play a more active role for peace. They helped create the Peace and Human Rights Network, which brought together women, media, youth, ex-militia members, sports groups and traditional elders to coordinate a peace making strategy. Many of the women crossed the lines demarcated by warring factions to advocate peace. Women's groundwork contributed immensely to the subsequent success of the peace efforts of the President of Djibouti and was acknowledged in a presidential statement of the Unite Nations Security Council (Frechette, 2001). On the whole, the poetry and networking with civil organization strategies initiatives adopted by Somalia women facilitated their incorporation in mediation and conflict resolution processes and helped to bring peace between the warring factions

\subsection{A case study of Kenya}

A commission report (2008) stated that, at the end of 2007 in Kenya, a violent electoral dispute was triggered by claims of rigging in the presidential elections. This led to deaths of 1,133 and displacement of over 300,000 Kenya people over a two month period. The Kenyan National Dialogue and Reconciliation (KNDR) process, under the auspices of Kofi Anan and the African Union Panel of Eminent African Personalities, sought to resolve this conflict at the end of January 2008. After 42 days of intense mediated negotiations, President Mwai Kibaki and Hon. Raila Odinga brought an end to the violence and political stalemate by signing a power sharing agreement (McGhie \& Wamai 2011). They further stated that, the Kenyan peace process involved a high level and high profile of women, with about 25percent of the members of the negotiating team being women. The women's involvement took many different forms, both at the local and national level. Women were engaged as members of the KNDR process, as senior advisors to the mediators, in mediation support roles, as senior members of the political delegation, and as civil society leaders.

One of the key processes employed by women in the mediation was the "spitting session" this session involved the coming together of Kenyan women from different party affiliations and ethnic groups, to raise all the issues that divided them. They got together to "spit" at each other and vent their anger in order to move forward. This "spitting" session allowed them to build confidence and trust in each other, and engage in a common ground on deep rooted issues affecting the crisis. In fact, this airing of differences gave birth to a unified women's voice that led to a Women's memorandum, which helped shape the long term issues, and formed an important part of the final peace agreement (Makumi \& Okello, 2006). As such, the 'spitting session' initiative employed by women strengthened their incorporation in the mediation and conflict resolution process in Kenyan, especially as they had a "unified voice".

Another strategy devised by women was that, during this period, Kenyan women formed a strong network locally, nationally, and internationally. Kenyan women were among the first to lobby at the African Union to testify to the US Congress, and to pass messages to senior figures in the UN and other capitals (Makumi \& Okello, 2006). This strategy helped to ensure that Kenyan women's voices were heard at the highest level of mediation and on the negotiation table, and must have contributed immensely to the achievement of the peace agreement. Such initiatives can be used by women to advance their integration at all levels of mediation and peace processes.

McGhien \& Wamai (2011) reported that, mediators involved in the Kenyan peace process felt that there was a difference between women being appointed to represent women's issues in particular and women representing a given political party or armed group. Some Kenyan female representatives expressed that they felt bound by the policies and politics of the party they represented, and therefore avoided focusing on the interests of women for fear of compromising their party's interest. This implies that, women negotiators in Kenya did not represent women's rights and interest in mediation, and conflict resolution processes but focused only on restoring peace without addressing women's needs. 
In addition to the above, Kenyan women were able to identify early warning signs of the conflict very differently from men. For example, the women were more sensitive to indicators and changes such as abduction, trafficking, hoarding of goods, sale of jewelry and weapons and increased propaganda etc before a conflict infact, many women leaders in Kenya were raising warnings in the months leading to the elections in 2007 (Makumi \& Okello, 2006; McGhien \& Wamai, 2011). But from all indications, it seems their warnings were not taken seriously. This naturally predictive asset of women can be used to their advantage in enhancing their participation in mediation and conflict resolution at all levels.

\section{LESSONS TO BE LEARNT}

The lessons learnt from both Somalia and Kenya case studies are not limited to, but include the following: The first and most significant lessons to be learnt, was the initiative taken by Somalia and Kenya women to unite and mobilize themselves irrespective of tribal, ethnic, and political affiliations to fight a common cause of peaceful co-existence in their countries. This process at that period, contributed immensely to eliminate all forms of discrimination in Kenya society that created a dysfunctional system of ethnic inequality. This means that for women to be actively integrated in mediation or peace building processes, they must have some level of consensus and a sense of unity amongst them, and a 'common voice', irrespective of culture, and other affiliation in the continent, and within each member state, because "united will women be integrated, divided will they be excluded". The ability to overcome social, economic and political differences and attain a unified voice is vital if women must fight their marginalization in mediation and conflict resolution processes. In both case studies, there was a strong communication and cooperation with women and civil society organizations during negotiations. This implies several issues; firstly, that that for women to effectively mediate in conflict, there must be a strong, active and consistent networking of women and civil society groups, since conflict prevention and resolution are often complex and too great for any single entity to deal adequately with. More so, because communities and disputants have trust and confidence in civil society actors due to their closeness to the communities involved, it is wise to network with them. In addition, networking also helps women's voices to be heard in peace processes. In both cases, civil society groups played a significant role to ensure the successful implementation of the agreement from both parties.

Secondly, the implication of networking of women and civil society organizations, helped women's voices to be heard at the highest level of mediation. This also indicates that, women can employ networking strategy with civil organizations to voice out their under-representation in peace processes, which may consequently lead to their increased involvement in the initiatives and processes. In Somalia, the networking strategy used by women gave them the courage to cross the lines demarcated by the warring factions to advocate for peace. Perhaps, this bold move in addition to the use of poetry may have also influenced the elders to agree to allocate women 12 percent in the administration.

Thirdly, In the case of Kenya, many women leaders were raising warning signs of a perceived conflict in the months leading up to the elections in 2007 (McGhie \& Wamai, 2011). However, it is assumed that these signals were under-rated and taken for granted by the key players in the political system. Thus a political crisis which could have been avoided if appropriate measure were instituted in response to the warnings, rather escalated and led to lost of lives and property. The impact of the conflict was reported by Anan (2011), to have shaken the foundation of the country to a point where it posed an existential threat to Kenya itself. In this light, it is expected that, the near accurate predictive asset of women should be used to their advance in clamoring for their inclusion in conflict resolution processes. Women's predictions should be voiced out and made known in every nook and cranny of the society, so that when such predictions materialize, all stake holders will appreciate the benefits of increasing women's participation in peace initiative. This is because, prediction of outcomes, foresight and good value judgment are vital assets in the realization of sustainable peace processes. This is also a warning signal to member countries never to ignore the "voices" of women. However, for women's voices to be heard, they must be active participants at all levels of these processes.

Lastly, but not the least, as earlier indicated, in Somalia, women's recitation of poetry was a powerful tool used by them to promote peace and secure their involvement in mediation and conflict resolution, hence, their allocation of 12 percent in parliament. This has shown that, it is important that each member country makes use of their own local theatre, art, drama, songs, riddles or whatever mediums their society places high premium on in conveying messages that can bring about peace. It could also be used as an avenue to create the awareness to all stake holders on the importance of women's involvement in peace processes. Even though 12 percent representation of women was inadequate, it created a stepping stone for women's incorporation in peace processes. The importance of each community identifying its own vital tool in mediation and changing the status quo of women, was exemplified as Ingirii (2009) reported that, the strategy of poetry was received positively because Somalia society places high value on poetry as an appropriate means of communication, not merely in times of peace and war, but also in times of prayer and travelling. 


\section{CHALLENGES}

Women do not priorities the inclusion and implementation of women's rights in peace processes: From the experiences of both Somalia and Kenya case studies enumerated above, and even for the rest of Africa, women do not represent women's rights and interests at the negotiation table. and as reported by McGhien \& Wamai (2011), women do not advance or address women's right or related issues like rape, and other forms of sexual assault etc, but are rather more concerned about ensuring peace and resolving conflict. It is important that conflicts are resolved to bring about peaceful co-existence and encourage societal development but, it is also extremely important that women's fundamental human rights are not violated during such conflicts. This is especially important with the increased use of sexual violence against women during conflict. This gap created by women mediators does not encourage the discussions on women's dignity, safety, and needs at the negotiation tables, neither does it facilitate the implementation of treaties, or agreements to stop this impunity. If women do not advance their course, men who are perpetrators of such actions are likely to keep mute over such issues.

Lack of trained women mediators and negotiators: There are insufficient trained women mediators in most African countries. Even where they exist, they are mostly involved at grass root, and local mediations, but absent in high profile mediation or negotiations where major decision-making takes place. This situation emanates mainly from the low educational status of African women perpetuated by patriarchal biases of sending male children to school, and denying the girl-child formal education. As long as African women remain largely uneducated, they will continue to encounter intimidation from men, especially as women are predominately poor. This is because education has a direct link with poverty, and poverty restricts the level of involvement of an individual in politics (power), and it is within the corridors of power and politics that fundamental decisions within almost every sphere of the society are taken. High illiteracy among women folk indicates that women are not adequately represented in politics or high profile mediations, official negotiations and post-settlement processes that can bring about significant positive changes in the status quo of women, and their needs. In 2010, the UN Development Fund for Women found out that women comprised less than 10 percent of negotiators and less than 3percent of the signatories to peace agreement. This situation does not guarantee active women's participation in all stages of peace processes as well as in conflict prevention

Non implementation of treaties: Even though most countries in Africa are signatories to treaties such as the Convention on the elimination of all Forms of Discrimination Against Women (CEDAW) 1971, Beijing Conference on women (1995), and the UN Security Council Resolutions (UNSCR) 1325(2000), which emphasizes the protection of women's fundamental human rights, and increased participation of women in decision making processes including those on mediation and conflict resolution, there seems to be slow or nonimplementation of such treaties. Unfortunately, women do not 'voice out' on the enforcement of such treaties. Men on the other hand, dominate in parliaments and in government, but do not prioritise implementation of treaties on women, especially with the 'weak voices' of women in lobbying for such implementations.

\section{PROSPECTS}

For the advancement of women's interest, it is important that in addition to mediating for peace, women must prioritize their interests and needs in all conflict resolution process. Furthermore, women should have representative who are specifically there to represent and discuss women's rights at mediation processes. Even though the United Nations (UN) condemns rape as an instrument of war, laws has to be enacted and implemented to project rape in conflict as crime against humanity, and provide laws to punish offenders of such acts. For its effective enforcement, African women have a huge responsibility to play in this regard, as it entails that, they mobilize women and form a strong delegate of women in each member state to lobby for these laws to be enacted and implemented at all levels. CMI \& WANEP (2011) posited that, "best practices" on gender based violence in peace mediations can be culled from Liberia and Cote d'Ivoire. The implementation of such treaties will catalyst the involvement of women in mediation and conflict resolution initiatives and processes.

To ensure the active participation of women mediators, there must be increased training of women in negotiating and mediating skills. In addition, women should be included in senior positions within their own existing structures of mediation and conflict resolution. This step will invariably increase women's participation at all levels of mediation processes. In the same vein, member states within the African region should also increase the number of women in senior positions in conflict prevention, management and post conflict peace talks. Potter (2008) posited that, peace processes that had significant involvement of women were found to be more legitimate and sustainable compared with those with little or no involvement of women. An indication that, women have deep insight and provide perspective which men may not deduce.

African women must lobby to ensure that the various conventions and treaties which protect women, and which their member countries are signatories to, are implemented. The importance of lobbying in achieving results was exhibited as McGhie \& Wmai (2011) reported that Kenya women were the first to lobby at the 
African Union, and to pass messages to senior figure in the UN and other capitals, their lobbying was critical in achieving sustainable peace agreements.

On a final note, there must be creation of awareness and sensitization of all stake holders from the local, national, regional and international level on the need and importance of actively involving women in both local and high profile peace talks. In Kenya for instance there was 25 percent involvement of women in negotiation and mediation processes, even though this percentage is not fair enough, it is commendable as compared to a smaller percentage of women's involvement in other parts of Africa. This move is crucial, considering the increasing realization that involving women in mediation and peace building has direct impact on stability and sustainable peace and development. This position was corroborated by a UNSCR (2008, 2009, 2010) assertion that more than 50percent of peace agreement fail within five years of signature partly because such talks suffer from the absence of women, especially as male negotiators and accords do not address the root cause of conflict, or seek to prevent a resurgence of conflict. Government, policy makers and the men at the negotiation table must be aware of this fact to ensure that more women are integrated in peace processes not only in Africa, but worldwide especially as no peace strategy is likely to be durable without the involvement of women.

\section{REFERENCES}

[1] Alexander, N (2009). International and Comparative Mediation: Legal Perspectives, Kluwer law International, Netherlands. Pp 27.

[2] Anan, K \& Nader. M (2012). Interventions: A life in War and Peace. The Penguin Press, Newyork

[3] Anneltto (2006). Guest at the table? The role of women in Sudan's Peace Processes. ACCORD,Issue18.

[4] Boulle, L (1996). Mediation : Principles, Process, processes and Practice. Sydney: Buterworth

[5] Crisis Management Initiative (CMI) and West Africa Network for Peace Building (WANEP) (2011). Workshop on " Gender based Violence and Peace Mediation in West Africa". November 29 $-30^{\text {th }} 2011$, Abuja, Nigeria.

[6] Frechette, L (2001). Speech delivered at the 'Women and Peace' Panel at United Nations Headquaters on the occasion of Internationa Women's Day.

[7] Ingirii,M (2012).www.insightonconflict.org/2012/08/.somali-women-conflict.

[8] Jama, F (2009) Whose place is it anyway? Connecting Somalia and international peacemaking. ACCORD Issue 21.

[9] Lynch, J (2001). "ADR and Beyond": A Systems Approach to Conflict Management", Negotiation Journal, Vol. 17, No. 3. Pp. 213

[10] Makumi \& Okello (2006) Rethinking Global Security, An African Perspective: Heinrich Boll Foundation, pp 86-104.

[11] McGhie \& Wamai (2011). Beyond the Numbers: Women's Participation in the Kenya National Dialogue and Reconciliation, Centre for Humanitarian Dialogue

[12] Potter (2008). Gender Sensitivity, Nicety or Necessity in Peace Process Management?, Centre for Humanitarian Dialogue, Geneva, pp 55-56

[13] Report by the Commission of Enquiry into the Post Election Violence, (Nairobi; Government printers, 2008).

[14] Todaro, G (2008). “Avoid Courts at all Costs”. The Australian Financial Review. No 14

[15] United Nations Security Council Resolution on women, peace and security (UNSCR). UNSCR 1820 (2008), UNSCR 1888(2009), and UNSCR 1960(2010) 